Original Research

\title{
Analysis of Sociodemographic and Information Factors on Family Behaviour in Early Detection of High-Risk Pregnancy
}

\author{
Ika Mardiyanti' ${ }^{1}$, Shrimarti Rukmini Devy'1, Ernawati Ernawati² \\ ${ }^{1}$ Faculty of Public Health, Universitas Airlangga, Surabaya, East Java, Indonesia \\ ${ }^{2}$ Faculty of Medicine, Universitas Airlangga, East Java, Indonesia
}

\begin{abstract}
Introduction: Pregnancy and childbirth are physiological processes experienced by women, but they sometimes have risky conditions. There are still many pregnant women and their families who are unable to detect a highrisk of pregnancy early. This study aims to determine family behaviour in conducting early detection of a high-risk of pregnancy in terms of sociodemographic and information factors.
\end{abstract}

Methods: This study uses an explanatory survey design with a cross sectional design. The sample size of this study was 146, with simple random sampling. The independent variables were sociodemographic factors (age, gender, ethnicity, education, income and religion) and information factors (experience, and media exposure) while the dependent variable is family behaviour. The instrument with the questionnaire used the Likert scale. The data was analysed using partial least square.

Results: The results showed that Structural Equation Modelling-Partial least square (SEM-PLS) statistical analysis, through Confirmatory Factor Analysis (CFA), obtained sociodemographic factors on family behaviour of 1,999 , and information factors on family behaviour of 13,78 . The value of the influence of sociodemographic factors (0.102) and the value of the influence of information factors (0.754). $R^{2}(0.63)$ and $Q^{2}$ value of 0.65 .

Conclusion: Sociodemographic factors and information factors significantly influenced family behaviour factors in early detection of high-risk of pregnancy. Information factors have a greater effect on family behaviour than sociodemographic factors. Midwives as health service providers at the health care centre need to optimize family empowerment through health information efforts in health promotion efforts. Further research requires the involvement of other factors to improve family behaviour, especially in the ability of families to detect early high-risk pregnancies.

\section{ARTICLE HISTORY}

Received: December 09, 2019

Accepted: December 26, 2019

\section{KEYWORDS}

behaviour; family; high-risk; pregnancy

\section{CONTACT}

Ika Mardiyanti

$\triangle$ ika.mardiyanti-

2017@fkm.unair.ac.id

$\supseteqq$ Faculty of Public Health,

Universitas Airlangga, Surabaya, East Java, Indonesia

Cite this as: Mardiyanti, I., Devy, S. R., \& Ernawati. (2019). Analysis of Sociodemographic and Information Factors on Family Behaviour in Early Detection ff High-Risk Pregnancy. Jurnal Ners, 14(2), 144-150. doi:http://dx.doi.org/10.20473/jn.v14i2.16561

\section{INTRODUCTION}

Pregnancy and childbirth are physiological processes experienced by a woman, but sometimes there are risky conditions (Holness, 2018). The ability of pregnant women to detect early high-risks is still below the average, which is one of the causes of complications that can endanger the welfare of the mother and foetus (Lee, Ayers, \& Holden, 2016).
For this reason there is a need for social support from family, friends, colleagues and health care providers to provide support to pregnant women, especially in risky conditions. This is especially important given the importance of maternal mental health during pregnancy (Wei et al., 2018).

National maternal mortality rate (MMR) from 1991-2015 has fluctuated. The results of the Indonesian Demographic and Health Survey (IDHS) 2017 showed a decrease in MMR during the 1991- 
2007 period from 390 to 228 per 100,000 KH, in 2012 it increased to 359 per $100,000 \mathrm{KH}$, in 2015 it decrease to 305 per 100,000 KH. Results of the 2015 Intercensal Population Survey (SUPAS) again showed a decline in MMR to 305 per $100,000 \mathrm{KH}$. The reduction in mortality has not yet reached the MDGs (Millennium Development Goals) target of reducing MMR to 102 per 100,000 KH in 2015 and is still far from SDGs (Sustainable Development Goals) output to reduce MMR to 70 per $100,000 \mathrm{KH}$ in 2030 (Ministry of Health Republic Indonesia, 2017).

Surabaya City is the highest regency / city in East Java with pregnant women experiencing obstetric complications of 9,496 out of 47,480 pregnant women in 2016 (Health Office of East Java Province, 2017). The number of high-risk pregnant women in 2015-2017 continued to increase, in 2015 amounted to 17,656 pregnant women, in 2016 amounted to 17,928 pregnant women, and in 2017 amounted to 19,698 pregnant women (Health Office of Surabaya, 2017).

The phenomenon in the community at this time is that there are still many pregnant women and their families who do not and are not able to perform early detection of a high-risk pregnancy. This is proven by the low coverage of early detection of high-risk by the community. Lack of community participation in early detection of high-risk of pregnancy is due to low levels of education and family knowledge, behaviour that is less supportive such as social position, economic ability and thus causes families to experience powerlessness in carrying out early detection of high-risk pregnancy (Khadijah \& ., 2018).

The factors affecting individuals as well as family, act among other things: personal factors (general attitudes, personality traits, values of life, emotions and intelligence), sociodemographic factors (age, gender, ethnicity, education, income and religion) and information factors (experience, knowledge, and media exposure) (Nursalam, 2017). Sociodemographic factors such as income and education can influence the condition of pregnant women and even depression (Biaggi, Conroy, Pawlby, \& Pariante, 2016).

The impact of early detection of highrisk pregnancy is not done optimally by the family, among others, is the occurrence of delays called 3 late. The first is late in recognizing danger signs of pregnancy and childbirth, the second is too late to make decisions, the third is too late to get to the hospital or referral is late. 3 late results in a higher maternal mortality rate (MMR) and infant mortality rate (IMR) (Fatkhiyah, Kodijah, \& Masturoh, 2018).

The family is expected to act as the closest support system for pregnant women, because in the family there are strong emotions to help take care of the mother during her pregnancy including in detecting abnormalities and danger signs (Joyce, Tully, Kirkham, Dicker, \& Breathnach, 2018). Early detection of symptoms and danger signs during pregnancy is the best effort to prevent the occurrence of serious disruption to pregnancy and maternal safety. Conducting early recognition of risk factors in pregnancy and childbirth as far as possible by pregnant women themselves, their husbands and families (Klugman, Li, Barker, Parsons, \& Dale, 2019).

Family behaviour in terms of sociodemographic factors and information can improve the ability of families, in this case the husband to participate in the care of pregnant women in recognizing the high-risk of pregnancy, and important aspects in caring for these pregnant women, as well as increasing family involvement in family empowerment. The purpose of this study was to determine family behaviour in conducting early detection of a high-risk of pregnancy in terms of sociodemographic and information factors.

\section{MATERIALS AND METHODS}

In this study, the design is an explanatory survey design with a cross sectional design. The population and sample are family. The independent variables are sociodemographic factors (age, gender, ethnic, education, income and religion) and information factors (experience, and media exposure) while the dependent variable is family behaviour.

The sample size of 146 respondents from the population pregnant women in the area around the Dupak Health Center is obtained by simple random sampling. This research was conducted in August to September 2019 in Puskesmas Dupak Health Center Surabaya, East Java. With the inclusion criteria of families who live together with pregnant women, and who play an important role in family decision maker. The questionnaire used the Likert scale. Exogenous variables (sociodemographic and information) and endogenous variables (family behaviour).

Valid indicators of social factors are education (0.76) and income (0.91), religious indicators (0.22) and gender (0.22) are quite valid. Education and income indicators have a significant effect on sociodemographic factors, religious and gender indicators also have a significant effect. Information factors are validly explained by experience indicators (1.00) and media exposure (0.30). So, the indicators of experience and media exposure have a significant effect on the information factor. Based on the composite reliability and Cronbach alpha values above which are worth more than 0.6 for sociodemographic factors (0.61), information (0.75) and family behaviour (1.0), it can be concluded that these factors are reliable (reliable) or consistent.

Data collection is done directly / primary data, and analysed by SEM-PLS, through CFA (Confirmatory Factor Analysis). Ethical clearance has 
been issued by the Airlangga University Faculty of Nursing Ethics Team No. 1752-KEPK in August 2019.

\section{RESULTS}

Data obtained from 146 respondents are presented in the Distributed Table.

Table 1 shows that the age of the respondents spread in all groups. Where the most age groups are $36-45$ years and $26-35$ years, respectively $35.6 \%$ and $30.8 \%$. The gender of the majority of male respondents was $89 \%$, education was spread at all levels, with the highest level of education being elementary education (SD-SMP) as much as $56.8 \%$ and secondary education (high school) as much as $31.5 \%$. The ethnic origin of respondents are almost entirely Javanese at $76 \%$, then Madura at $23.3 \%$. The income of the respondents is almost entirely in the sufficient category which is $80.8 \%$; and the religion practiced by almost all Islam/Muslims is $83.6 \%$.

Related information variables with experience indicators (54.8\%) had received counselling and for indicators of media exposure almost all (89.7\%) were exposed to media in the form of posters. In regard to family behaviour related to actions taken by family members in carrying out family tasks in early detection of a high-risk of pregnancy, it is known that the achieved or positive behaviour is $52.7 \%$, while that which is not achieved or the behaviour towards negative is $47.3 \%$.

\section{Analysis of measurement models}

The process of analysing the measurement model is done by testing the validity and reliability of the factor variables. Indicator criterion indicators concluded valid measuring the factor variables, if the loading factor value has the value of $t$-statistics $\geq t$ table or if the value of $t$-statistics of the weight of influence $\geq \mathrm{t}$-table $=\mathrm{t}_{(\mathrm{n}-1 ; 5 \% / 2)}=\mathrm{t}_{(92 ; 0.025)}=$ 1.96. While it is concluded invalid if the factor loading value and the influence weight value both have tstatistic values $<1.96$. The next tests the consistency / reliability of the factor variables by using composite reliability and alpha Cronbach values. The criterion that the factors concluded reliable is explained by the indicator variables, if the composite value $>0.7$ then the consistency of the factors is good, and if the value of 0.6 to 0.7 is still acceptable. It is known that all indicator variables have t-statistics values more than $\mathrm{t}$-table values $=1.96$. There are only 2 indicators that do not reach 1.96 and are still above 1 , so the conclusion is quite significant.

Indicators of valid sociodemographic factors are education and income, religious and gender indicators are valid enough to explain sociodemographic factors. Education and income indicators have a significant effect on
Table 1. Frequency distribution of sociodemographic, information, and family behaviour variables $(n=146)$

\begin{tabular}{|c|c|c|c|}
\hline Indicator & Sub Indicator & $\mathbf{n}$ & $\%$ \\
\hline \multicolumn{4}{|c|}{ Sociodemographic } \\
\hline Age (years & $17-25$ & 16 & 11.0 \\
\hline \multirow[t]{5}{*}{ old) } & $26-35$ & 45 & 30.8 \\
\hline & $36-45$ & 52 & 35.6 \\
\hline & $46-55$ & 27 & 18.5 \\
\hline & $56-65$ & 5 & 3.4 \\
\hline & $>65$ & 1 & 0.7 \\
\hline \multirow[t]{2}{*}{ Gender } & Male & 130 & 89.0 \\
\hline & female & 16 & 11.0 \\
\hline \multirow[t]{3}{*}{ Education } & Basic & 83 & 56.8 \\
\hline & Intermediate & 46 & 31.5 \\
\hline & High & 17 & 11.6 \\
\hline \multirow[t]{4}{*}{ Ethnic } & Java & 111 & 76.0 \\
\hline & Madura & 34 & 23.3 \\
\hline & China & 1 & 0.7 \\
\hline & Batak & 0 & 0 \\
\hline \multirow[t]{2}{*}{ Income } & High & 28 & 19.2 \\
\hline & Enough & 118 & 80.8 \\
\hline \multirow[t]{5}{*}{ Religion } & Islam & 122 & 83.6 \\
\hline & Christian & 24 & 16.4 \\
\hline & Catholic & 0 & 0 \\
\hline & Hindu & 0 & 0 \\
\hline & Buddha & 0 & 0 \\
\hline \multirow[t]{2}{*}{ Experience } & Ever & 80 & 54.8 \\
\hline & Not yet & 66 & 45.2 \\
\hline \multirow{3}{*}{$\begin{array}{l}\text { Media } \\
\text { exposure }\end{array}$} & Poster & 131 & 89.7 \\
\hline & Leaflet & 7 & 4.8 \\
\hline & Not exposed & 8 & 5.5 \\
\hline \multicolumn{4}{|c|}{ Family behaviour } \\
\hline \multirow{2}{*}{$\begin{array}{l}\text { Family } \\
\text { behaviour }\end{array}$} & Reached & 77 & 52.7 \\
\hline & Not achieved & 69 & 47.3 \\
\hline
\end{tabular}

sociodemographic factors, religious and gender indicators have a significant effect. Information factors are explained validly by indicators of experience and media exposure. So, it can be concluded that the indicators of experience and media exposure significantly influence the information factor.

Based on the value of composite reliability and Cronbach alpha. which are worth more than 0.6 for sociodemographic factors, information and family behaviour, it can be concluded that the factors mentioned above are reliable (reliable) or consistent.

\section{Analysis of Structural Model Testing}

Analysis of the structural model testing to evaluate several criteria, namely the significance criteria of the coefficient of influence of exogenous variables (sociodemographic and information) of the endogenous variable (behavioural family), then the criteria of the coefficient of determination $\left(\mathrm{R}^{2}\right)$, and predicted relevance $\left(Q^{2}\right)$. Significance criteria of the coefficient of influence of sociodemographic factors and information factors on family behaviour factors, 


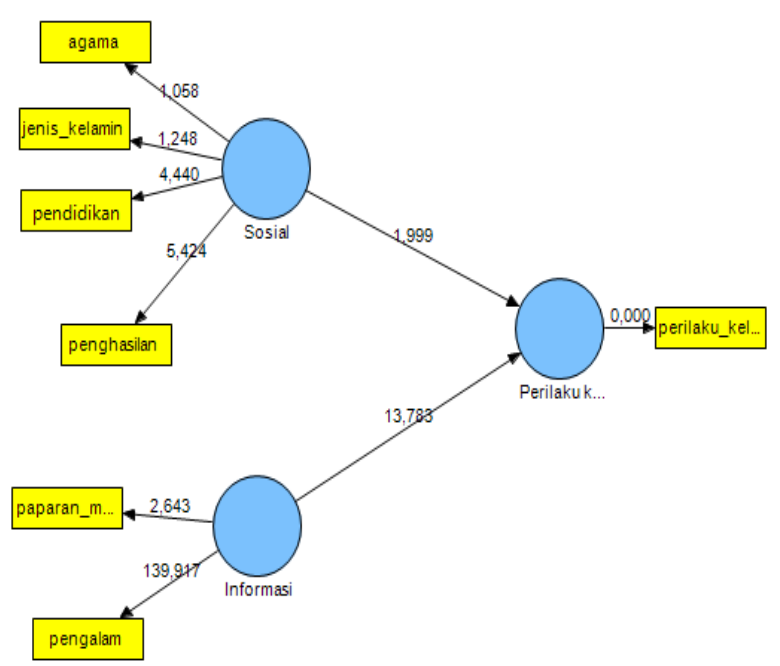

Figure 1. Value of loading factor and t-statistics value of the model

by testing using t-statistics values which are then compared with t-table values.

The results of testing the effect of the coefficient of influence between sociodemographic factors and information factors on family behaviour in early detection of high-risk of pregnancy, that the $t$ statistics between sociodemographic factors on family behaviour is 1.999 where above the t-table value of 1.96, it is concluded that sociodemographic factors have a significant effect towards family behaviour. Furthermore, the t-statistic value of the information factor on family behaviour is 13.78 where above the t-table value of 1.96 it is concluded that the information factor has a significant effect on family behaviour.

The value of the influence of sociodemographic factors on family behaviour is 0.102 , where the value of the influence is linear in the same direction which means that if sociodemographic factors are increased by 1 unit it will increase family behaviour in the early detection of high-risk of pregnancy, with the effect of an increase of 0.102 times. The value of the influence of information factors on family behaviour is 0.754 , where the value of the influence is linear in the direction which means that if the information factor is increased by 1 unit it will increase family behaviour in the early detection of high-risk of pregnancy, with the effect increasing by 0.754 times.

Results of processing coefficient of determination (R2) of the influence of sociodemographic factors and factors of information on family behavioural factors in the early detection of high-risk pregnancies, amounting to 0.63 . So this value is included in the criteria both in terms of large variations of endogenous factors (family behaviour) that can be explained by exogenous factors (sociodemographic and information). The processing results obtained Q2 value of 0.65 . This value is included in the criteria of having a good ability (relevant) in predicting.

\section{DISCUSSION}

The sociodemographic factors examined in this study concern age, sex, education, ethnicity, income and religion. Sociodemographic factors have the effect of increasing family behaviour in the detection of highrisk of pregnancy by 0.102 times and the information factor has the effect of increasing family behaviour in the detection of high-risk of pregnancy by 0.754 times.

In this study almost half in the late adult age group 36-45 years (35.6\%) and early adults 26-35 years $(30.8 \%)$. In family members who are old enough the level of maturity and strength of the family will be more mature in thinking and acting. This is seen from the experience and maturity of his soul. Age is one of the factors that influence one's health behaviour (Lin, Broström, Nilsen, \& Pakpour, 2018).

Support obtained from husbands, families and health workers is very important in recognizing the symptoms and responses felt by pregnant women (Zand et al., 2017). In this research, in the majority of respondent families, 89\% were accompanied by their husband. Husband support is particularly beneficial in reducing anxiety and complications in pregnancy (Abdollahpour, Ramezani, \& Khosravi, 2015). Support, especially from couples, is very influential in making decisions (Alemayehu \& Meskele, 2017).

Family education is mostly elementary education (elementary-junior high) at 56.8\%. The lack of community participation in the early detection of high-risk of pregnancy is due to low levels of education and knowledge, and low income resulting in unsupportive behaviour. Education is one way for families to receive knowledge about antenatal care, with high education and good knowledge which will make families easy to receive information and conduct early detection of high-risk pregnancies (Mehta, Zheng, \& Myrskylä, 2019).

Table 2. Convergent validity of latent variables

\begin{tabular}{|c|c|c|c|c|}
\hline \multirow[t]{2}{*}{ Latent Variable } & \multirow[t]{2}{*}{ Indicator } & \multicolumn{3}{|c|}{ Convergent Validity } \\
\hline & & Loading factor $(\lambda)$ & T Statistics & Validity \\
\hline \multirow[t]{4}{*}{ sociodemographic } & Religious & 0,22 & 1,06 & Valid Enough \\
\hline & Gender & 0,22 & 1,25 & Valid Enough \\
\hline & Education & 0,76 & 4,44 & Valid \\
\hline & Income & 0,91 & 5,42 & Valid \\
\hline \multirow[t]{2}{*}{ Information } & exposure media & 0,30 & 2,64 & Valid \\
\hline & experience & 1,00 & 139,92 & Valid \\
\hline
\end{tabular}


Table 3. Path Coefficients: effect of sociodemographic and information on family behaviour

\begin{tabular}{lccccc}
\hline Indicators & $\begin{array}{c}\text { Original } \\
\text { Sample (0) }\end{array}$ & $\begin{array}{c}\text { Sample } \\
\text { Mean (M) }\end{array}$ & $\begin{array}{c}\text { Standard } \\
\text { Deviation }\end{array}$ & $\begin{array}{c}\text { Standard } \\
\text { Error }\end{array}$ & $\begin{array}{c}\text { T- } \\
\text { Statistics }\end{array}$ \\
\hline Religious <- sociodemographic & 0.215 & 0.210 & 0.203 & 0.203 & 1.058 \\
Gender <- sociodemographic & 0.225 & 0.212 & 0.180 & 0.180 & 1.248 \\
Exposure media <- information & 0.304 & 0.299 & 0.115 & 0.115 & 2.643 \\
Education <- sociodemographic & 0.764 & 0.713 & 0.172 & 0.172 & 4.439 \\
Experience <- information & 0.999 & 0.994 & 0.007 & 0.007 & 139.917 \\
Income <- sociodemographic & 0.909 & 0.865 & 0.168 & 0.168 & 5.424 \\
Information & 0.754 & 0.752 & 0.0555 & 0.0555 & 13.78 \\
->Family behaviour & 0.102 & 0.110 & 0.051 & 0.051 & 1.999 \\
sociodemographic ->Family behaviour & & & & &
\end{tabular}

The origin of respondents is almost entirely Javanese $76 \%$ and Madura 23.3\%. Indigenous peoples' knowledge about health advice can be good information in supporting education and behaviour for pregnant women of certain ethnicities. For example, in Madura many dietary restrictions and food suggestions are applied for pregnant women. This affects the patterns of habits and behaviour of pregnant women and their families (Diana et al., 2018). Culture has a strong influence on decision making. Family participation in perinatal care is very important (Tobing, Afiyanti, \& Rachmawati, 2019).

Income shows that almost all (80.8\%) respondents have a sufficient income level. It is important for financial income to meet the daily needs of households in the community, specifically with financing, then someone will be able to utilize the existing health facilities such as treatment and control that can still maintain the health of pregnant women. This income is very influential on family behaviour, including pregnant women. A good level of income allows family members to meet better needs, for example in the fields of education, health, career development and so on. Health care professionals should carefully assess the state of family empowerment of primary caregivers who are younger and those with low education, low household income, high burden of child-rearing, and ties are fragile among the members of the family. Home visits and institutional services for the provision of care and services are well coordinated (Wakimizu, Fujioka, Nishigaki, \& Matsuzawa, 2018).

Religion, at almost $83.6 \%$, is almost entirely Muslim. Religion is published about life in humans, published in humans. The existence of such rules can provide guidance to families in how to care for and respond to families who are pregnant. Spirituality strongly influences Muslims in supporting spiritual values during pregnancy and childbirth, nurses must be sensitive to women's spirituality and integrate this element in providing maternal nursing care (Budiati \& Setyowati, 2019).

The information factors examined in this study include experience and media exposure. Most respondents $(54.8 \%)$ had the experience of respondents from the study results who had received counselling about risky pregnancy. In addition, most respondents consider themselves experienced when children also have experiences about other people who have already been pregnant. A collaborative education model using multi-disciplines for patient education will be very important to provide information related to assistance provided to support maternal mortality and morbidity (Jain \& Moroz, 2017).

In this study nearly half (89.7\%) of respondents were exposed to the media related to high-risk pregnancies in poster form. Respondents obtained information about high-risk pregnancies from posters or leaflets provided at Puskesmas, as well as electronic media, and counselling by health workers. Media information about the detection of high-risk of pregnancy can affect one's knowledge (Dewi, 2017).

The results of this study showed the majority of family behaviour reached $52.7 \%$. Information factors have a greater effect on family behaviour in the detection of high-risk of pregnancy. Information about high-risk pregnancies provided by health workers both print and electronic media will increase the knowledge of pregnant women and their families about the importance of early detection of high-risk pregnancies so that they can be encouraged to do so. The role of health workers in providing information about high-risk pregnancies is very important (Widarta, Cahya Laksana, Sulistyono, \& Purnomo, 2015). The role of the government in providing information about high-risk pregnancies greatly helps pregnant women and families to obtain better information (Waryana, Supadi, \& Haryani, 2016).

The information factor on family behaviour is 0.754 greater than the sociodemographic factor. A more proactive approach to providing information may be valuable not only for those who have a clear desire for more information, but also for those who are unsure of what information they might have missed (Baron et al., 2017).

The behaviour of the family in performing early detection of high-risk pregnancies in influenced by a person's health beliefs (Health belief) in theory HBM (Health Belief Model). HBM (Health Belief Model) is used to identify several important priority factors that have an impact on behaviour (Huang, Dai, \& Xu, 2020). 
Azwar (2013) stated that according to the theory of planned behaviour, among the various beliefs, the availability of opportunities and resources are the reason to determine intention and attitude. This belief can be derived from the experience, and also it can be influenced by indirect information about behaviour, for example by looking at the experience of a friend or someone else. It is also influenced by several other factors that reduce or increase the effect of the difficulty committing acts.

Human behaviour occurs through a stimulusorganism-response process. The behaviour in question is family behaviour in the early detection of high-risk pregnancies in which behaviour is associated with factors of age, education, income, knowledge, experience and media exposure. In fact, the role of the husband and the family also influences pregnant women in supporting the behaviour or actions of pregnant women in utilizing health services (Chou et al., 2018).

A person's health behaviour is determined, among other things, by the presence or absence of support from the surrounding social support, in this case midwives are the main health care providers during pregnancy, they should ideally emphasize the availability of questions during antenatal examinations (Baron et al., 2017). People who live in an environment that upholds health aspects will be more enthusiastic in maintaining their health (Yeh, Ma, Huang, Hsueh, \& Chiang, 2016). Maternal and child health needs to be improved, so in an effort to improve the holistic and integrative approach is not only limited to the medical sector, but also economically, educationally and socio-culturally (Asmuji. \& Indriyani, 2016). The involvement of families as caregivers is to improve their health status (Chimowitz, Gerard, Fossa, Bourgeois, \& Bell, 2018). The limitation in this research is that it only relates to sociodemographic and information factors. While there are other factors that also influence family behaviour in detecting early high-risk pregnancies.

\section{CONCLUSION}

There are social factors and information factors that need to be considered to improve family behaviour in pregnancy care. The information factor has a larger comparison than sociodemographic factors. Family problems can improve the quality of the family in approval of danger signs or problems experienced in the family. Midwives as health service providers at the health care centre need to optimize family empowerment through health information efforts in health promotion efforts. Further research needs an optimal family empowerment model that makes families need help during pregnancy and participates in preventing the presence of maternal and infant applications.

\section{REFERENCES}

Abdollahpour, S., Ramezani, S., \& Khosravi, A. (2015). Perceived social support among family in pregnant women. International Journal of Pediatrics. https://doi.org/10.22038/ijp.2015.4703

Alemayehu, M., \& Meskele, M. (2017). Health care decision making autonomy of women from rural districts of Southern Ethiopia: A community based cross-sectional study. International Journal of Women's Health. https://doi.org/10.2147/IJWH.S131139

Asmuji., \& Indriyani, D. (2016). Model Family Centered Maternity Care sebagai strategi Optimalisasi Competent Mothering. Ners Airlangga. https://doi.org/http://dx.doi.org/10.20473/jn.V 11I12016.17-28

Azwar, S. (2013). Sikap Manusia: Teori dan Pengukurannya. Sikap Manusia: Teori Dan Pengukurannya. https://doi.org/10.1038/cddis.2011.1

Baron, R., Heesterbeek, Q., Manniën, J., Hutton, E. K., Brug, J., \& Westerman, M. J. (2017). Exploring health education with midwives, as perceived by pregnant women in primary care: A qualitative study in the Netherlands. Midwifery. https://doi.org/10.1016/j.midw.2017.01.012

Biaggi, A., Conroy, S., Pawlby, S., \& Pariante, C. M. (2016). Identifying the women at risk of antenatal anxiety and depression: A systematic review. Journal of Affective Disorders. https://doi.org/10.1016/j.jad.2015.11.014

Budiati, T., \& Setyowati. (2019). The influence culture and maternal care on exclusive breastfeeding practice in post caesarean section mothers. Enfermeria Clinica. https://doi.org/10.1016/j.enfcli.2019.04.121

Chimowitz, H., Gerard, M., Fossa, A., Bourgeois, F., \& Bell, S. K. (2018). Empowering Informal Caregivers with Health Information: OpenNotes as a Safety Strategy. Joint Commission Journal on Quality and Patient Safety. https://doi.org/10.1016/j.jcjq.2017.09.004

Chou, J. L., Pierce, K. J., Pennington, L. B., Seiler, R., Michael, J., Mc Namara, D., \& Zand, D. (2018). Social Support, Family Empowerment, Substance Use, and Perceived Parenting Competency during Pregnancy for Women with Substance Use Disorders. Substance Use and Misuse. https://doi.org/10.1080/10826084.2018.14674 56

Dewi, R. G. A. I. (2017). Pengaruh Kemampuan Ibu Hamil Dalam Melakukan Deteksi Dini Risiko Preeklamsia Terhadap Paritas, Pengetahuan Dan Keterpaparan Informasi. Medical Technology and Public Health Journal. https://doi.org/10.33086/mtphj.v1i1.275

Diana, R., Rachmayanti, R. D., Anwar, F., Khomsan, A., Christianti, D. F., \& Kusuma, R. (2018). Food taboos and suggestions among Madurese pregnant women: a qualitative study. Journal of Ethnic Foods. https://doi.org/10.1016/j.jef.2018.10.006

Fatkhiyah, N., Kodijah, K., \& Masturoh, M. (2018). 
Determinan Maternal Kejadian Preeklampsia: Studi Kasus di kabupaten Tegal, Jawa Tengah. Jurnal Keperawatan Soedirman. https://doi.org/10.20884/1.jks.2016.11.1.642

Health Office of East Java Province. (2017). Profil Kesehatan Jawa Timur 2017. In Profil Kesehatan Jawa Timur.

Health Office of Surabaya. (2017). Profil Dinas Kesehatan Kota Surabaya. In Dinas Kesehatan.

Holness, N. (2018). High-Risk Pregnancy. Nursing Clinics of North America. https://doi.org/10.1016/j.cnur.2018.01.010

Huang, X., Dai, S., \& Xu, H. (2020). Predicting tourists' health risk preventative behaviour and travelling satisfaction in Tibet: Combining the theory of planned behaviour and health belief model. Tourism Management Perspectives. https://doi.org/10.1016/j.tmp.2019.100589

Jain, J., \& Moroz, L. (2017). Strategies to reduce disparities in maternal morbidity and mortality: Patient and provider education. Seminars in Perinatology. https://doi.org/10.1053/j.semperi.2017.04.010

Joyce, N. M., Tully, E., Kirkham, C., Dicker, P., \& Breathnach, F. M. (2018). Perinatal mortality or severe neonatal encephalopathy among normally formed singleton pregnancies according to obstetric risk status:" is low risk the new high risk?" A population-based cohort study. European Journal of Obstetrics and Gynecology and Reproductive Biology. https://doi.org/10.1016/j.ejogrb.2018.06.010

Khadijah, S., \& . A. (2018). Upaya Deteksi Dini Resiko Tinggi Kehamilan Ditentukan Oleh Pengetahuan Dan Dukungan Tenaga Kesehatan. Jurnal Sehat Mandiri. https://doi.org/10.33761/jsm.v13i1.2

Klugman, J., Li, L., Barker, K. M., Parsons, J., \& Dale, K. (2019). How are the domains of women's inclusion, justice, and security associated with maternal and infant mortality across countries? Insights from the Women, Peace, and Security Index. SSM - Population Health. https://doi.org/10.1016/j.ssmph.2019.100486

Lee, S., Ayers, S., \& Holden, D. (2016). Risk perception and choice of place of birth in women with high risk pregnancies: A qualitative study. Midwifery. https://doi.org/10.1016/j.midw.2016.03.008

Lin, C. Y., Broström, A., Nilsen, P., \& Pakpour, A. H. (2018). Using extended theory of planned behavior to understand aspirin adherence in pregnant women. Pregnancy Hypertension. https://doi.org/10.1016/j.preghy.2018.04.001

Mehta, N. K., Zheng, H., \& Myrskylä, M. (2019). How do age and major risk factors for mortality interact over the life-course? Implications for health disparities research and public health policy. SSM - Population Health. https://doi.org/10.1016/j.ssmph.2019.100438

Ministry of Health Republic Indonesia. (2017). Profile Kesehatan Indonesia 2017. Ministry of Health Indonesia. https://doi.org/10.1002/qj

Nursalam. (2017). Metodologi penelitian ilmu keperawatan: pendekatan praktis. In Metodologi penelitian Iimu keperawatan: pendekatan praktis.

Tobing, V. Y., Afiyanti, Y., \& Rachmawati, I. N. (2019). Following the cultural norms as an effort to protect the mother and the baby during the perinatal period: An ethnographic study of women's food choices. Enfermeria Clinica. https://doi.org/10.1016/j.enfcli.2019.04.125

Wakimizu, R., Fujioka, H., Nishigaki, K., \& Matsuzawa, A. (2018). Family empowerment and associated factors in Japanese families raising a child with severe motor and intellectual disabilities. International Journal of Nursing Sciences. https://doi.org/10.1016/j.ijnss.2018.09.006

Waryana, W., Supadi, S., \& Haryani, W. (2016). Empowering Women's Organizations For Anemia Prevention And Control In Trimurti Village, Srandakan Sub-District, Bantul, Yogyakarta, Indonesia. Belitung Nursing Journal. https://doi.org/10.33546/bnj.36

Wei, D. M., Au Yeung, S. L., He, J. R., Xiao, W. Q., Lu, J. H., Tu, S., ... Qiu, X. (2018). The role of social support in family socio-economic disparities in depressive symptoms during early pregnancy: Evidence from a Chinese birth cohort. Journal of Affective Disorders. https://doi.org/10.1016/j.jad.2018.06.014

Widarta, G. D., Cahya Laksana, M. A., Sulistyono, A., \& Purnomo, W. (2015). Deteksi Dini Risiko Ibu Hamil dengan Kartu Skor Poedji Rochjati dan Pencegahan Faktor Empat Terlambat. Majalah Obstetri \& Ginekologi. https://doi.org/10.20473/mog.v23i1.2100

Yeh, H. Y., Ma, W. F., Huang, J. L., Hsueh, K. C., \& Chiang, L. C. (2016). Evaluating the effectiveness of a family empowerment program on family function and pulmonary function of children with asthma: A randomized control trial. International Journal of Nursing Studies. https://doi.org/10.1016/j.ijnurstu.2016.04.013

Zand, D. H., Chou, J. L., Pierce, K. J., Pennington, L. B., Dickens, R. R., Michael, J., ... White, T. (2017). Parenting self-efficacy and empowerment among expectant mothers with substance use disorders. Midwifery. https://doi.org/10.1016/j.midw.2017.03.003 